\title{
Attitude of Students Towards Academic Dishonesty in UMT
}

\author{
Zaki Ullah Khan \\ M.Phil. Sociology Scholar, University of management and Technology, Lahore \\ Khadija \\ M.Phil. Sociology Scholar, University of management and Technology, Lahore
}

\begin{abstract}
Researchers conducted an investigation into the occurrence of students' academic dishonesty at the University of Management and Technology by using quantitative method. Students' academic dishonesty in University of Management and technology has become a major issue in recent years due to advancement in technology. This study explores the factors that influence the behavior of students and make them dishonest. The study largely supports the students understanding to the academic dishonesty and plagiarism. The university faculties have failed to deliver proper awareness regarding students' academic dishonest behavior and about university policies of academic dishonesty. However, indigenous knowledge of faculty's focal persons helped them in a greater context to keep them somewhat safe from academic dishonesty. For this study, simple random sampling technique is used by taking 400 participants/respondents from University of Management and technology. Researchers check the seriousness of cheating regarding student's different types of behavior in reference to various kinds of academic dishonesty. It is hoped that the findings of this research can be used to understand the issues around academic dishonesty and developed ways of supporting students in order to reduce its occurrence.

Keywords: Academic dishonesty, cheating, attitude, students.
\end{abstract}

DOI: $10.7176 / \mathrm{JEP} / 10-1-07$

\section{Background of the study}

A strong educational system provides a solid base on which the development of country is made. Therefore, the standard of education is the most important thing for the development in all fields and areas of life. That's why Higher education plays an essential role in society, creating new knowledge, transferring it to students and developing innovation (Schultz, 2008). The primary purpose of education is to promote learning among students and enhance the motivation and raising tolerance permitting students to make significant contribution towards society. Higher learning is not only focuses on academic learning but also depend on social and moral development of students within educational experience (Wood, 2009)

Pakistan has a lot of youth in the age group who can benefit from higher education. Youth literacy rates was $57 \%$ in 2014. Current Pakistan's youth literacy rate is $71 \%$, with males at $79 \%$ and females at $61 \%$.Youth literacy rate definition covers the population between the ages of 15 to 24 years. In the last few years, Pakistan has shown considerable progress in the higher education sector. The government has also enhanced its spending on the university sector. Standards have been set by the Higher Education Commission and authorizing bodies have been established to ensure a uniform and quality education in both public and private universities. (HEC, 2013-14).

Education plays a vital role in development of a country so the education which is for purpose of learning is most important than education which is only for the sake of getting degree. Academic dishonesty is increasing, and there are many factors behind it due to this reason one prefers academic dishonesty over academic integrity. Our responsibility to instruct good basic values among students from their childhood.

Due to financial security and personal reasons this thinking that grades are important, significantly effecting the lives of students. The students' priority on achieving higher academic grades seriously fetters the achievement of moral and social values. The overall result of such academic experience is not holistic (Wood, 2009). Sometimes they go for cheating plagiarism and cheating is reflection of need to get good marks at any cost, and this wrong approach will continue to become serious problem in their academia and this problem is damaging our educational system. Academic dishonesty consists of any attempts to falsifying, fabricate or tempering with data information, record or any other material that is relevant to the student's perception in any course or other academic exercise or function (Levine McCabe, \& Tribble, 2001; McCabe, Trivano, \& Butterfield, 2001; Vowell, 2000) Plagiarism or academic dishonesty is seen as a wide-Ranging and growing problem identified, Plagiarism is a shared practice and prevailed in university life. (Martin, 2009) The researcher explore the questions like: What are the factors that lead student's engagement in dishonest behavior? Secondly, how can we check the students' seriousness about academic dishonest? And also: What is plagiarism according to students' perception? 


\section{Research problem:}

It is very important to read this phenomenon because it creates disorder in educational institutes and society as well. In Pakistan, now increase in plagiarism, fabricating, falsifying data, deception and cheating being highlighted and these are question on academic integrity. However, this study aims to identify students' perceptions and factors of academic dishonesty. So, this study would offer the students' behavior about seriousness in academic integrity.

\section{Research objectives}

1) To investigate the factors that leads student engagement in dishonest behavior.

2) To investigate the seriousness of students about academic dishonesty.

3) To investigate the understanding of students about Plagiarism and cheating in UMT.

\section{Significance of the study}

The significance of this study is that it applies quantitative research techniques to analyze the cheating behavior that UMT students endure and the level or degree of their seriousness about the specific behaviors that are considered cheating. This study offers to bridge the gaps between students' perceptions, factors and reasons that influence students to cheat and to be dishonest. And this study would offer the students' worldview and perceptions about the environment for academic integrity and experiences regarding it. This study will help teachers 'instructors and policy makers who are concerned about the substance of plagiarism, cheating and academic dishonesty and understand how students' perceive or conceptualize the phenomenon of academic dishonesty and academic integrity.

\section{Literature review}

Cheating behavior is a complex psychological, social and situational phenomenon (Leming, 1980, p.86). There is a perception that student academic dishonesty has increased since the 1990's with the availability of accessible computer technology and the creation of the World Wide Web. Although these technologies have increased the ratio of academic dishonesty, particularly copy-and-paste plagiarism, easier they have not created a new problem. Significant levels of student academic dishonesty have been reported from as early as 1941 (Davis, Grover, Becker, \& McGregor, 1992).

Extensively researched had been done on insistent nature of students that include multi-faceted and complex factors. However, we can't make differentiation into a single category of this complex group of behaviors called "cheating" which can create difficulties when examining the field of academic dishonesty. In this study the diversity of behaviors were divided into three broad groups - plagiarism, test and examination cheating and fabrication and falsification and when viewed holistically can be "described by sets of practices that encompass illegal, unethical and immoral behaviors and behaviors that are against generally accepted institutional practices" (Martin, Sheard, \& Hasen, 2007 p.2).

\section{Plagiarism}

Plagiarism is one of the principal areas of research in this field as it is the most commonly reported form of student academic dishonesty after unpermitted collaboration and occurs at much higher levels than other forms of academic dishonesty. The various types of plagiarism are often collapsed into the encompassing term of "cheating" in different studies and this term carries an interpretation and implication about the behavior. It predicts deviancy, dishonesty and a level of consideration that does not occur when plagiarism is identified in other social environments. Outlined how scholarly plagiarism and social plagiarism are distinguished with plagiarism in texts such as biographies, autobiographies, political speechwriting, and in policies for government, church and trade unions regarded as acceptable with little negative reaction from wider society. The misattribution of authorship in these domains arises from unequal power relationships between junior and senior members of the organization in question and credit for others work is regularly taken by those in senior positions (Martin, 1994).

A similar situation has occurred in academic publishing when superior academics put their name to publications or research when they are not the principal authors reflecting the same power imbalance and misattribution of authorship. When students engage in scholarly plagiarism this is generally condemned and punished and can attract strongly negative and emotional reactions from teaching staff (Park, 2004). In higher education institutions students and staff are expected to reference all sources used in academic work. This contrasts to common social experiences in society, particularly for young students, where the reproduction and distorting of ideas, images and language in comedy shows, films, blogs, $\mathrm{T}$ shirt slogans and many other social arenas is regarded as acceptable and maybe even clever and desirable (although it may breach copyright law) (Bowman, 2004). As states "it is hard not to feel that language use is marked far more by the circulation and recirculation of words and ideas than by a constant process of creativity" (Pennycook, 1996, p.227). 


\section{Theoretical framework:}

The researcher uses social learning theory as a theoretical framework. The social learning theory is a behavioral revision approach found in social psychology. This theory was covered by Sutherland's association theory. The individuals who have develop the social learning thus are of the opinion that norm violating actions are learned behavior which have been attained by the similar process of acceptable behavior. I will now demonstrated the Social learning theory throughout my research through communication, with other either the student learn academic dishonesty or to obtain from it. The peer group and family often have more influence on a college and university student's behavior. This honesty and dishonesty deviant deems the behavior favorable then it becomes a part of his or her norm. Through a moral perspective a student will either approve of cheating or refrain from it. If he or she disapprove that behavior fore flowed was outcome has a greater award and less risk at being caught. Hence if the act is of deviant nature or complying with society norms that act will be repeated in this case the reward and cost which may be predicted from the attainment of better grades could be balance with a chance to discover or getting caught in which case negative sensations are imposed.

\section{Hypothesis of the research:}

- Association between student's engagement in dishonest behavior and seriousness of cheating.

- Association between informed cheating policies at UMT and occurrence of cheating during a test or examination.

- Association between student's engagements in dishonest behavior in relation to their study.

- Association between seriousness of cheating behavior in relation to their study.

\section{Research methodology}

The research conducted in this study was Quantitative research. Quantitative research is a formal, objective, systematic process in which numerical data are used to obtain information about the world (Burns \& Grove, 2005). Quantitative research can be used in response to relational questions of variables within the research. The data analysis usually proceeds by using statistics, charts and tables etc. The findings from quantitative research can be predictive, explanatory, and confirming. This study was carried out at University of Management and technology Lahore. I collected the required data for my research from this institute. The population of this study was students of University of Management and technology Lahore. I collected my data from these people with their consent so that I could achieve my goal with their cooperation. Total sample size was 400 respondents. I gathered my data from 400 people who were associated with the University of Management and technology. I randomly asked people to fill our questionnaire. Without their consent, I did not get any information. I used Random sampling to pursue my data collection. I asked anyone to fill the questionnaire with their consent and share the information with me. The questionnaire used for the survey in this study used structured questions which consisted of closed-ended questions and demographic part consists of both open ended and closed-ended questions. The Questionnaire consists of 3 sections and contain 15questions. The data collected was checked and edited for clarity, reliability, validity and relevance. For processing data, SPSS 21 will be used to analyze data in the form of frequency, data coding was also used. In this research, the techniques used for the data analysis are descriptive Statistics, inferential statistics, univariate analysis, Bi-variate analysis.

\section{Conclusion and findings}

There have been different factors of student's dishonest behavior. These factors are proved with strong arguments in the light of theory. Plagiarism, cheating, fabrication, falsification, disruption and imitation are the main types of academic dishonesty being highlighted in the current study. The phenomena have been supported with the social learning theory. Students neutralized their violation of norms and deviant acts of academic dishonesty by blaming education institution system. Moreover, this study has also been operated the scenario of strain theory which bring light on this issue in this way life stressors are important prediction of criminal behavior. Researchers have found that students who reported in order to want better marks, grades, parents and family pressure to succeed and to get good job are more likely to engage in dishonest behavior. Analysis results showed that there is a significant positive weak relationship between seriousness of cheating, gender, study year, time commitments, student's grades cheating policies and dishonest behavior. The findings of this research indicated that cheating behavior can be reduced through employing social learning theory and strain theory. It is also proved that strain theory has effect on academic performance the society.

\section{Recommendation}

After conducting this research, the researchers have the following the recommendations for futures researches.

- It is vital for the educator and educational institutions to pay extra attentions in planning, extracurricular activities in schools, colleges and University. Educator must do every effort to engage students in these activities. Extracurricular may act as a buffer to neutralized academic stressors. These activities can 
enhance self-esteem of those students who may be average but may hold different talent. This will not only allow students to be relieved of stress and enhance their self-esteem but will also allow maintaining good physical, psychological and social health.

- Additional research is needed regarding student's cheating, comprehensive understanding of student's perceptions of academic integrity policies and practices, observations and reporting of cheating, engagement in cheating behavior and seriousness of cheating must be gained.

- Institutions should develop clear policies and procedures for identifying academic dishonesty and work towards a shared understanding of academic dishonesty among all the students of UMT.

- The Institution should also have specified who is responsible for implementing academic policies, openly communicate policies to the campus, provide training or managing academic dishonesty and offer assistance, in implementing academic integrity.

- There should be a consensus on the definition of cheating and plagiarism and academic world should take responsibility of this consensus and description the phenomenon in detail.

- A plagiarism advisory service should be formed on global level. There should be one academic policy regarding plagiarism all over the world so that cultural and demographic factors could not complicate the matter anymore.

- Higher education policy regarding plagiarism needs some practical tutorials, seminars and lectures so that the gap between policy and practice can be bridged.

\section{References}

A popculture perspective. In V. Bowman (Ed.), the plagiarism plague. New York: Neal Schuman CAI. (1999).

Aaron, R. M., \& Georgia, R. T. (1994). Administrator perceptions of student academic dishonesty in collegiate instititutions. NASPA Journal, 31, 83-91.

Agnew, Robert (2001). "Building on the Foundation of General Strain Theory: Specifying the Types of Strain Most Likely to Lead to Crime and Delinquency". Journal of Research in Crime and Delinquency. 38 (4): 319-361. Doi: 10.1177/0022427801038004001.

Akers, R.L. 1977. Deviant Behavior. Belmont, CA: Wadsworth. 1985. Deviant Behavior (2nd ed.). Belmont, CA: Wadsworth

Akers, R.L., M.D. Krohn, L. Lanza-Kaduce, and M. Radosevich. 1979. “'Social learning and deviant behavior: A specific test of a general theory." American Sociological Review, 44, 636-655.

Aluede, Oyaziwo ve Eunice O. Omoregie ve Gloria I. Osa-Edoh (2006). "Academic Dishonesty As a Contemporary Problem in Higher

American Psychological Association (2001). Publication Manual of the American Psychological Association (5th ed). Washington, D.C. : American Psychological Association.

Asgnew, Robert (2014). "General Strain Theory". Journal of Research in Crime and Delinquency: 1892-1900

Ashworth, P., Bannister, P., \& Thorne, P. (1997). Guilty in whose eyes: University students' perception of cheating and plagiarism. Studies in Higher Education, 22, 187203.

Assessment \& Evaluation in Higher Education, 31(5), 485-503. Creswell, J. W. (2003). Research design: Qualitative, quantitative and mixed methods approaches (2nd ed.). Thousand Oaks, CA: Sage. Creswell, J. W., \& Plano Clark, V. L. (2007).

Bandura, A. (1986). Social foundations of thought and action. Englewood Cliffs, NJ: Prentice-Hall.

Belter, R.W. \& du Pre, A. (2009). A strategy to reduce plagiarism in an undergraduate course. Teaching of Psychology, 36(4), 257-261

Bensman, Joseph. 1988. "The aesthetics and politics of footnoting." Politics, Culture, and Society. 1:443-470.

Blakstone, A.(2012) . Principles of Sociological Inquiry :Qualitative and Quantitative Method, College of Education and Human Development, Available at http:/www.opem2umn.edu

Blankenship, K. L., \& Whitley, B. E. (2000). Relation of general deviance to academic dishonesty. Ethics \& Behavior, 10(1), 1-12.

Bolin, A. (2004). Self-control, perceived opportunity and attitudes as predictors of academic dishonesty. The Journal of Psychology, 138(2), 101-114. de Lambert, K., Ellen, N., \& Taylor, L. (2006).

Boston: Pearson Education Sutherland-Smith, W. (2003). Hiding in the shadows: Risks and dilemmas of plagiarism in student academic writing. Paper presented at the International Education Research Conference, Auckland New Zealand.

Bryman, A., \& Bell, E. (2007). Planning a research project and formulating research questions. Business research methods, 75-92.

Burns, N., \& Grove, S. K. (2005). The practice of nursing research: Conduct, critique and utilization (5th ed.). St. Louis, MO: Elsevier Saunders.

Bushway and Nash, 623, Wilfried Decoo, Crisis on Campus: Confronting Academic Misconduct (Cambridge,Mass.: MIT Press, 2002), 23. Patrzek, J.; Sattler, S.; van Veen, F.; Grunschel, C.; Fries, S. 
(2014). \&quot; Investigating theeffect of academic procrastination on the frequency and variety of academic misconduct: a panel study\&quot;. Studies in Higher Education: 1-16. doi:10.1080/03075079.2013.854765. Brian Aaron Jacob \&amp; Steven D. Levitt (2003) Catching Cheating Teachers: The Results of an Unusual Experiment in Implementing Theory\&quot; available at Project Muse. William J. Bowers, Student Dishonesty and its Control in Colleges (New York: Bureau of Applied Social Research, Columbia University, 1964), 155.

Chalkface challenges: A study of academic dishonesty amongst students in New Zealand tertiary institutions.

Cohen, L., Manion, L., \& Morrison K. (2000). Research Methods in Education (5 ${ }^{\text {th }}$ Edition). London: Routledge Falmer

Cole S,\&Conklin ,D,(1996),Academic Integrity Policies and Procedures: Opportunities to Teach Students about the Moral Leadership and Personal Ethics, College Student Affairs Journal ,15(2),30-39.

Davis, S. F., Grover, C. A., Becker, A. H., \& McGregor, L. N. (1992). Academic dishonesty: Prevalence, determinants, techniques, and punishments. Teaching of Psychology, 19(1), 16-20.

Designing and conducting mixed methods research. Thousand Oaks, CA: Sage. LaBeff, E. E., Clark, R. E., Haines, V. J., \& Diekhoff, G. M. (1990).

Donald L. McCabe and Linda Klebe Trevino, \&quot;Academic Dishonesty: Honor Codes and Other Contextual Influences\&quot; , The Journal of Higher Education 64, no. 5, (September-October 1993), 532.

Education: How Academic Advisers Can Help," ERIC No: EJ765511. Merton, R.K. Entwicklung und Wandel von Forschungsinteressen. Aufsätze zur

Emily E. LaBeff, et al., \&quot;Situational Ethics and College Student Cheating\&quot; Sociological Inquiry 60, no. 2 (May 1990), 192

Eriksson, L. \& McGee, T. R. (2015). Academic dishonesty amongst Australian criminal justice and policing university students: individual and contextual factors.

Factors associated with cheating among college students: A Review. Research in Higher Education, 39(3), 235274.

Fanelli, D. (2009). How many scientists fabricate and falsify research? A systematic review and meta-analysis of survey data. PloS one, 4(5), e5738.

Gottfredson M. R., Hirshci T. (1990). A General Theory of Crime. Stanford, CA: Stanford University Press.

Graham,M.A, Monday,J.,O Brien,K, \&,Steffon,S.(1994).Cheating at small colleges:An examination of student and faculty attitudes and behaviors.Journal of College Student Department,16(2)777-790.

Hiding in the shadows: Risks and dilemmas of plagiarism in student academic writing. Paper presented at the International Education Research Conference, Auckland New Zealand. Whitley, B. E., Jr. (1998).

International Journal for Educational Integrity, 11(5). doi: 10.1007/s40979-015- 0005-3.

Internationalisation - Practical Solutions: A Trans-Tasman Workout, ISANA 16th Annual Conference Sutherland-Smith, W. (2003).

Johnson, S. A., \& Martin, M. (2005). Academic dishonesty: A new twist to an old problem. Athletic Therapy Today, 10(4), 48-50. Arvidson C. J. (2004). 